\title{
Temperature Boundary Condition Models for Concrete Bridge Members
}

\author{
by Kyle A. Riding, Jonathan L. Poole, Anton K. Schindler, Maria C. G. Juenger, and Kevin J. Folliard
}

The temperature development of mass concrete elements is strongly dependent on constituent materials and mixture proportions, as well as the formwork type, geometry, and environmental conditions. This paper presents a method to account for the effects of convection, radiation, and shading on the surface temperature of mass concrete. Solar radiation, atmospheric radiation, surface-emitted radiation, and formwork radiation exchange were considered. Wind speed, ambient temperature, and surface roughness were included in the convection model. The model described was incorporated into a mass concrete temperature prediction model. The predicted temperatures were then compared with measured near-surface concrete temperatures. The ability of the model to predict the maximum temperature and maximum temperature difference were also examined. The results show that the model accurately estimates the near-surface concrete temperatures, the maximum temperature, and maximum temperature difference of the 12 concrete members instrumented.

Keywords: formwork; mass concrete; temperature prediction.

\section{INTRODUCTION}

Large quantities of heat are released during the exothermic hydration process in concrete, which in turn raises the concrete temperature. In recent years, larger bridge members, increased cement fineness, and greater amounts of cement in concrete mixtures have increased the temperature rise in concrete bridge members. Concern over thermal cracking and delayed ettringite formation $(\mathrm{DEF})^{1}$ in these members has spurred interest in developing temperature prediction models for mass concrete bridge members.

Heat transfer and temperature prediction of a concrete member involves a number of interrelated mechanisms, none of which has a closed-form solution. Each of these mechanisms must be modeled, and a solution determined iteratively. The analysis may be divided into three main components: the heat generation from the hydration process, the heat conduction in the concrete, and the heat exchanged at the boundary of the structural element. This paper will focus on the heat exchange with the environment and boundary conditions as they pertain to mass concrete elements.

There is a body of literature ${ }^{2,3}$ that deals with methods to account for the heat generated by cement hydration. The most commonly used method combines the equivalent age maturity method and an exponential degree of hydration curve to characterize the rate of heat generation. This method is well documented in other papers, and is shown in Eq. $(1)^{2,3}$

$$
\begin{gathered}
Q_{h}(t)=H_{u} \times C_{c} \times\left(\frac{\tau}{t_{e}}\right)^{\beta} \times\left(\frac{\beta}{t_{e}}\right) \times \alpha_{u} \\
\times \exp \left(-\left[\frac{\tau}{t_{e}}\right]^{\beta}\right) \times \exp \left(\frac{E}{R}\left(\frac{1}{273+T_{r}}-\frac{1}{273+T_{c}}\right)\right)
\end{gathered}
$$

where $Q_{h}$ is the rate of heat generation $\left(\mathrm{J} / \mathrm{h} / \mathrm{m}^{3}\right) ; H_{u}$ is the total amount of heat generated at $100 \%$ hydration $(\mathrm{J} / \mathrm{kg}) ; C_{c}$ is the total amount of cementitious materials $\left(\mathrm{kg} / \mathrm{m}^{3}\right) ; \tau$ is the hydration time parameter, in hours; $t_{e}$ is the concrete equivalent age at the reference temperature, in hours; $\beta$ is the hydration slope parameter; $\alpha_{u}$ is the ultimate degree of hydration (unitless); $E$ is the activation energy $(\mathrm{J} / \mathrm{mol}) ; R$ is the universal gas constant $(\mathrm{J} / \mathrm{mol} / \mathrm{K}) ; T_{r}$ is the reference temperature $\left({ }^{\circ} \mathrm{C}\right)$; and $T_{c}$ is the concrete temperature $\left({ }^{\circ} \mathrm{C}\right)$.

The conductive properties of concrete are well covered in literature. Heat conduction in the concrete is dependent on the moisture content, density, specific heat, and thermal conductivity of the concrete. The specific heat and thermal conductivity of concrete is dependent on the mixture proportions, temperature, and degree of hydration of the concrete. ${ }^{3}$ Aggregates play an especially important role in the conductive properties of concrete.

The discussion of boundary conditions in literature is less thorough. Most of the work reported has been done on horizontal surfaces, mainly bridge decks and pavements. ${ }^{4-6}$ The boundary conditions of the concrete member are the most complex and variable portion of the heat transfer analysis. The modeling of the concrete heat exchange with the environment is dependent on the surrounding features such as walls and ground surfaces, formwork, curing blankets, ambient conditions, orientation of the element, and heat conduction from the concrete interior. ${ }^{7}$ Radiation and convection are especially dependent on these parameters. A review of the theory behind these heat transfer mechanisms is thus warranted and is provided in this paper.

Radiation exchange with the environment involves incoming and outgoing components. Solar radiation, radiation from the atmosphere, radiation from the surrounding surfaces, and radiation from the formwork bracing can all impact the surface temperature of the concrete and can be considered heat sources. Irradiation (radiation emitted by the formwork) and reflected radiation act as heat sinks. Figure 1 illustrates the different radiation and convection surface boundary conditions from the environment to the outside formwork of a column.

Convection transfer on the outside of concrete members consists of free and forced convection. Free convection is the heat transfer due to bulk fluid movement (due to buoyancy forces from the temperature differences in the air during heat exchange) and diffusion of the fluid (usually air or

ACI Materials Journal, V. 104, No. 4, July-August 2007

MS No. M-2006-189 received May 8, 2006, and reviewed under Institute publication policies. Copyright (C) 2007, American Concrete Institute. All rights reserved, including the making of copies unless permission is obtained from the copyright proprietors. Pertinent discussion including authors' closure, if any, will be published in the May-June 2008 ACI Materials Journal if the discussion is received by February 1, 2008. 
ACI member Kyle A. Riding is a PhD Candidate at the University of Texas at Austin, Austin, Tex. He received his BS from Brigham Young University, Provo, Utah, and his MS from the University of Texas at Austin. He is a member of ACI Committee 201, Durability of Concrete.

ACI member Jonathan L. Poole is an Engineer at Wiss, Janney, Elstner Associates, Inc. He received his $B S, M S$, and $P h D$ from the University of Texas at Austin. He is a member of ACI Committee 207, Mass Concrete.

ACI member Anton K. Schindler is an Assistant Professor in the Department of Civil Engineering at Auburn University, Auburn, Ala. He received his MSE and PhD in civil engineering from the University of Texas at Austin. He is a member of ACI Committees 211, Proportioning Concrete Mixtures; 231, Properties of Concrete at Early Ages; 237, Self-Consolidating Concrete; and E803, Faculty Network Coordinating Committee.

ACI member Maria C. G. Juenger is an Assistant Professor of Civil, Architectural, and Environmental Engineering at the University of Texas at Austin. She received $P h D$ in materials science and engineering from Northwestern University, Evanston, Ill. She is a member of ACI Committees 201, Durability of Concrete; 231, Properties of Concrete at Early Ages; 236, Material Science of Concrete; and E802, Teaching Methods and Educational Materials.

ACI member Kevin J. Folliard is an Assistant Professor in the Department of Civil, Architectural, and Environmental Engineering at The University of Texas at Austin. He received his $P h D$ in civil engineering from the University of California-Berkeley, Berkeley, Calif., in 1995. He received the ACI Young Member Award for Professional Achievement in 2002. He is a member of the ACI Publication Committee and ACI Committee 201, Durability of Concrete.

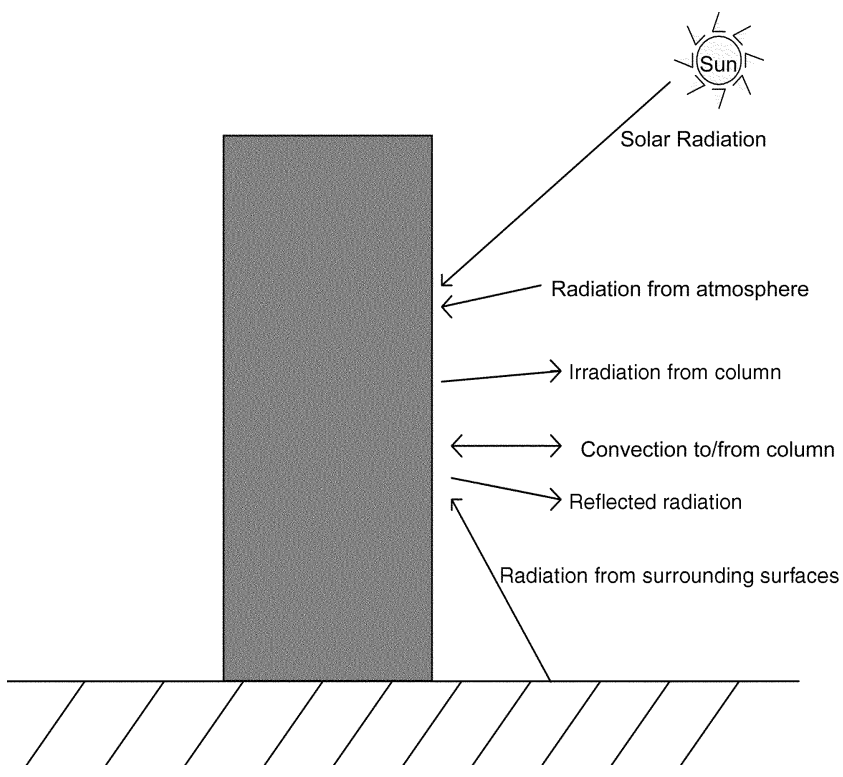

Fig. 1-Summary of column boundary conditions. water for concrete members) around the member. Forced convection is the heat transfer from bulk fluid movement caused by the wind. ${ }^{8}$

Despite the apparent complexity of temperature prediction, there is a systematic approach that produces an accurate solution. The heat transfer at boundary conditions may be calculated using the finite difference method. The finite difference method may be approached by using an energy balance for differential volumes; the sum of the energy in minus the sum of the energy out equals the change in energy (and thus temperature) of a control volume. The approach allows for the treatment of each boundary condition effect separately at each time step. ${ }^{8}$

This paper reviews several models for calculating the heat transfer at concrete member boundaries, with emphasis placed on those for vertical surfaces. Next, the paper discusses the incorporation of these models into a mass concrete temperature prediction model. Finally, a comparison is made between the predicted temperatures from the temperature prediction model to measured temperatures from 12 concrete bridge structures.

\section{RESEARCH SIGNIFICANCE}

Changing concrete member dimensions, mixture proportions, and material properties in recent years have led to temperature-related problems in mass concrete bridge elements. Concrete temperature modeling is being used to help avoid any problems that may occur from excessive temperatures. Correct boundary condition modeling of concrete bridge members is an essential part of any temperature prediction model. This paper presents a model for temperature boundary condition modeling of mass concrete structures, focusing especially on the vertical surfaces. Model results are also compared with measured temperatures from mass concrete bridge elements.

\section{EXPERIMENTAL METHODS Concrete member instrumentation}

Twelve concrete members were instrumented to record the temperature during the first few days after concrete placement. The concrete members instrumented were selected to give a wide variety of geometries, materials, formwork, ambient conditions, and curing conditions. Table 1 shows a summary of the concrete member size and construction sequences. The rectangular bent cap, T-shaped bent cap, and pedestal were constructed with wood forms. Concrete was placed against the embankment in Footing 2. The remainder of the

Table 1-Concrete member summary

\begin{tabular}{c|c|c|c|c|c|c}
\hline Member & Placement date $(\mathrm{M} / \mathrm{D} / \mathrm{Y})$ & Length, $\mathrm{m}(\mathrm{ft})$ & Width, $\mathrm{m}(\mathrm{ft})$ & Height, $\mathrm{m}(\mathrm{ft})$ & Placement time & Formwork removed, days \\
\hline Pedestal & $06 / 11 / 04$ & $2.9(9.5)$ & $3.2(10.5)$ & $1.7(5.5)$ & $10: 00$ a.m. & $>7$ \\
\hline T-shaped bent cap & $06 / 05 / 04$ & - & $2.2(7.2)$ & $2.5(8)$ & $8: 00$ a.m. & 2.25 \\
\hline Rectangular bent cap & $03 / 31 / 04$ & - & $1.0(3.2)$ & $1.0(3.2)$ & $8: 00$ a.m. & 5 \\
\hline Dolphin 1 & $02 / 05 / 04$ & $4.9(16)$ & $4.9(16)$ & $2.7(9)$ & $11: 30$ a.m. & 5 \\
\hline Dolphin 2 & $09 / 10 / 04$ & $4.9(16)$ & $4.9(16)$ & $2.7(9)$ & $4: 15$ a.m. & 4 \\
\hline Footing 1 & $08 / 06 / 03$ & $2.4(7.9)$ & $1.8(6)$ & $2.0(6.5)$ & $10: 00$ a.m. & 4 \\
\hline Footing 2 & $08 / 01 / 03$ & $3.1(10)$ & $3.1(10)$ & $1.9(6)$ & $8: 00$ a.m. & - \\
\hline Footing 3 & $08 / 06 / 03$ & $2.4(7.9)$ & $1.8(6)$ & $2.0(6.5)$ & $8: 00$ a.m. & \\
\hline Footing 4 & $08 / 09 / 04$ & $18.3(60)$ & $4.1(13.5)$ & $2.0(6.5)$ & $5: 00$ a.m. & \\
\hline Column 1 & $07 / 10 / 04$ & $1.8(6)$ & $3.1(10)$ & $20.4(67)$ & $8: 00$ a.m. & $>14$ \\
\hline Column 2 & $06 / 11 / 04$ & $2.6(8.5)$ & $3.1(10)$ & $12.2(40)$ & $8: 30$ a.m. & 5 \\
\hline Pilaster & $02 / 22 / 05$ & $2.7(9)$ & $1.8(6)$ & $1.7(5.5)$ & $9: 00$ a.m. & $>7$ \\
\hline
\end{tabular}


Table 2-Concrete member mixture proportions

\begin{tabular}{|c|c|c|c|c|c|c|c|c|c|}
\hline Member & \begin{tabular}{|c|} 
Cement, \\
$\mathrm{kg} / \mathrm{m}^{3}\left(\mathrm{lb} \mathrm{yd}^{3}\right)$ \\
\end{tabular} & \begin{tabular}{|c|}
$\mathrm{SCM}$, \\
$\mathrm{kg} / \mathrm{m}^{3}\left(\mathrm{lb} / \mathrm{yd}^{3}\right)$ \\
\end{tabular} & \begin{tabular}{|c|} 
Water, \\
$\mathrm{kg} / \mathrm{m}^{3}\left(\mathrm{lb} / \mathrm{yd}^{3}\right)$
\end{tabular} & $\begin{array}{l}\text { Fine aggregate, } \\
\mathrm{kg} / \mathrm{m}^{3}\left(\mathrm{lb} / \mathrm{yd}^{3}\right)\end{array}$ & $\begin{array}{c}\text { Coarse aggregate, } \\
\mathrm{kg} / \mathrm{m}^{3}\left(\mathrm{lb} / \mathrm{yd}^{3}\right)\end{array}$ & SCM type & \begin{tabular}{|c|} 
Coarse \\
aggregate type
\end{tabular} & $\begin{array}{c}\text { Fine } \\
\text { aggregate type }\end{array}$ & $\begin{array}{l}\text { Chemical } \\
\text { admixtures }\end{array}$ \\
\hline Pedestal & $295(497)$ & $106(179)$ & $164(279)$ & $1035(1745)$ & 681 (1147) & $\mathrm{F}$ & $\mathrm{Cl}$ & SNS & LRWR \\
\hline $\begin{array}{l}\text { T-shaped } \\
\text { bent cap }\end{array}$ & $241(409)$ & $86(143)$ & $154(259)$ & 1034 (1743) & 799 (1347) & $\mathrm{F}$ & $\mathrm{Cl}$ & SNS & LRWR \\
\hline $\begin{array}{l}\text { Rectangular } \\
\text { bent cap }\end{array}$ & $251(423)$ & 64 (107) & $126(212)$ & 1108 (1867) & 727 (1225) & $\mathrm{C}$ & $\mathrm{CG}$ & CG & LRWR \\
\hline Dolphin 1 & $253(426)$ & $100(168)$ & 123 (207) & $1112(1874)$ & 687 (1157) & $\mathrm{F}$ & SRG & SNS & $\begin{array}{l}\text { LRWR } \\
\text { MRWR }\end{array}$ \\
\hline Dolphin 2 & $244(411)$ & 109 (189) & 123 (207) & 1084 (1827) & 670 (1129) & $\mathrm{F}$ & SRG & SNS & $\begin{array}{l}\text { LRWR } \\
\text { MRWR }\end{array}$ \\
\hline Footing 1 & $253(426)$ & 64 (107) & $135(228)$ & 1041 (1754) & 845 (1424) & $\mathrm{F}$ & CL & SNS & LRWR \\
\hline Footing 2 & $253(426)$ & 64 (107) & $135(228)$ & $1041(1754)$ & 845 (1424) & $\mathrm{F}$ & $\mathrm{CL}$ & SNS & LRWR \\
\hline Footing 3 & $253(426)$ & 64 (107) & $135(228)$ & $1041(1754)$ & 845 (1424) & $\mathrm{F}$ & $\mathrm{CL}$ & SNS & LRWR \\
\hline Footing 4 & $167(282)$ & $133(224)$ & $104(175)$ & 1109 (1869) & 793 (1337) & $\mathrm{F}$ & SRG & SNS & $\begin{array}{l}\text { LRWR } \\
\text { HRWR }\end{array}$ \\
\hline Column 1 & $251(423)$ & 64 (107) & $131(223)$ & $1035(1745)$ & 847 (1427) & $\mathrm{F}$ & $\mathrm{CL}$ & SNS & LRWR \\
\hline Column 2 & $295(497)$ & $106(179)$ & $164(279)$ & $1035(1745)$ & $681(1147)$ & $\mathrm{F}$ & $\mathrm{Cl}$ & SNS & LRWR \\
\hline Pilaster & $181(305)$ & $165(278)$ & $149(250)$ & 997 (1680) & 746 (1258) & GGBFS & SRG & SRG & MRWR \\
\hline
\end{tabular}

concrete members were built using uninsulated steel forms. Table 2 shows the concrete mixture proportions. Semiadiabatic calorimetry was performed on-site for each concrete mixture; Table 3 shows the concrete hydration parameters as measured by semi-adiabatic calorimetry. Adiabatic temperature development curves were calculated from the semi-adiabatic tests using the procedure suggested by RILEM technical Committee $119 .{ }^{9}$ Over 33,000 hours of temperature data from 137 temperature sensors were collected for comparison with the predicted concrete temperatures. Of the 137 temperature sensors, 66 were

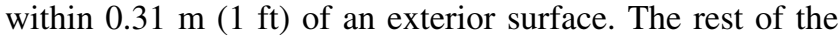
sensors were placed at varying distances from the surface to capture conduction effects of the concrete temperature development at different locations inside the concrete core.

\section{Instrumentation procedure}

A commercial on-site weather station that measured air temperature, humidity, wind speed, wind direction, and solar radiation was used. The weather station was programmed to collect weather data each hour. All temperature sensors were programmed to record and log the temperature at 15-minute intervals. The procedures for modifying the sensors for access outside of the concrete member were similar to those used in an earlier study. ${ }^{10}$ Each temperature sensor was placed to best capture the core and edge temperatures in each concrete member. The location of each temperature sensor in the concrete member was recorded.

\section{Weather data}

\section{ANALYTICAL METHODS}

The boundary conditions in concrete temperature prediction models are a function of the ambient conditions. The temperature prediction model contains weather files for 239 U.S. cities and data from these files are used in heat transfer calculations. The weather files contain hourly 30-year average weather data calculated from the National Climatic Data Center (NCDC) Solar and Meteorological Surface Observational Network (SAMSON) CDs. ${ }^{11}$ The weather data used in the temperature prediction model use the global horizontal solar radiation, extraterrestrial horizontal solar radiation, barometric pressure, dry bulb temperature, relative humidity, and wind speed data from this database in the
Table 3-Hydration parameters as measured by semi-adiabatic calorimetry

\begin{tabular}{c|c|c|c|c|c}
\hline Member & $\alpha_{u}$ & $\beta$ & $\tau$, hours & $E, \mathrm{~J} / \mathrm{mol}$ & $H_{u}, \mathrm{~J} / \mathrm{kg}$ \\
\hline Pedestal & 0.920 & 0.704 & 30.9 & 38,100 & 456,500 \\
\hline $\begin{array}{c}\text { T-shaped } \\
\text { bent cap }\end{array}$ & 0.983 & 0.672 & 32.4 & 38,200 & 456,500 \\
\hline $\begin{array}{c}\text { Rectangular } \\
\text { bent cap }\end{array}$ & 0.860 & 0.655 & 21.8 & 39,600 & 492,000 \\
\hline Dolphin 1 & 0.714 & 0.993 & 16.9 & 29,400 & 456,000 \\
\hline Dolphin 2 & 0.724 & 0.782 & 23.6 & 29,400 & 451,500 \\
\hline Footing 1 & 0.806 & 0.652 & 23.3 & 39,600 & 465,500 \\
\hline Footing 2 & 0.806 & 0.652 & 23.3 & 39,600 & 465,500 \\
\hline Footing 3 & 0.806 & 0.652 & 23.3 & 39,600 & 465,500 \\
\hline Footing 4 & 0.755 & 0.520 & 37.6 & 40,000 & 445,500 \\
\hline Column 1 & 0.720 & 0.616 & 25.9 & 41,300 & 493,500 \\
\hline Column 2 & 0.920 & 0.704 & 30.9 & 38,100 & 456,500 \\
\hline Pilaster & 1.000 & 0.444 & 59.0 & 41,200 & 536,900 \\
\hline
\end{tabular}

Note: $1 \mathrm{~J} / \mathrm{kg}=0.00043 \mathrm{BTU} / \mathrm{lb}$

calculations. The relative humidity, wind speed, and dry bulb temperature used in the calculations can be scaled by the user by manually inputting maximum and minimum daily values. Solar radiation values can be adjusted indirectly by changing average daily cloud cover values.

A linear relationship between cloud cover and solar radiation is assumed as shown in Eq. (2) 12,13

$$
E_{H}=(0.91-(0.7 \times C)) \times E_{T O A}
$$

where $E_{H}$ is the surface horizontal solar radiation $\left(\mathrm{W} / \mathrm{m}^{2}\right), C$ is the cloud cover fraction, and $E_{T O A}$ is the extraterrestrial horizontal solar radiation $\left(\mathrm{W} / \mathrm{m}^{2}\right)$.

\section{Radiation}

Radiation may be defined as "energy emitted by matter that is at a finite temperature." " There are several different ways in which energy is given off or absorbed by a surface. These include solar radiation, radiation exchange between form elements, atmospheric radiation, ground radiation, and column irradiation. The following sections will discuss the theories used to model the different sources of radiation and irradiation. 


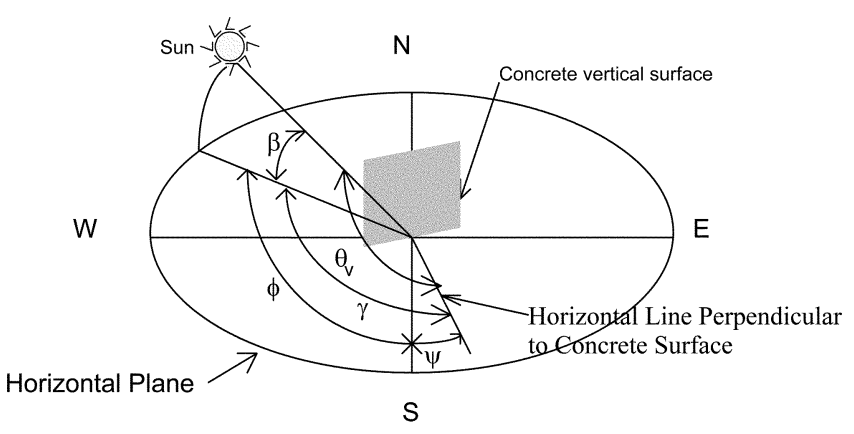

Fig. 2-Angles used for calculation of angle of solar incidence on concrete surface. ${ }^{15}$

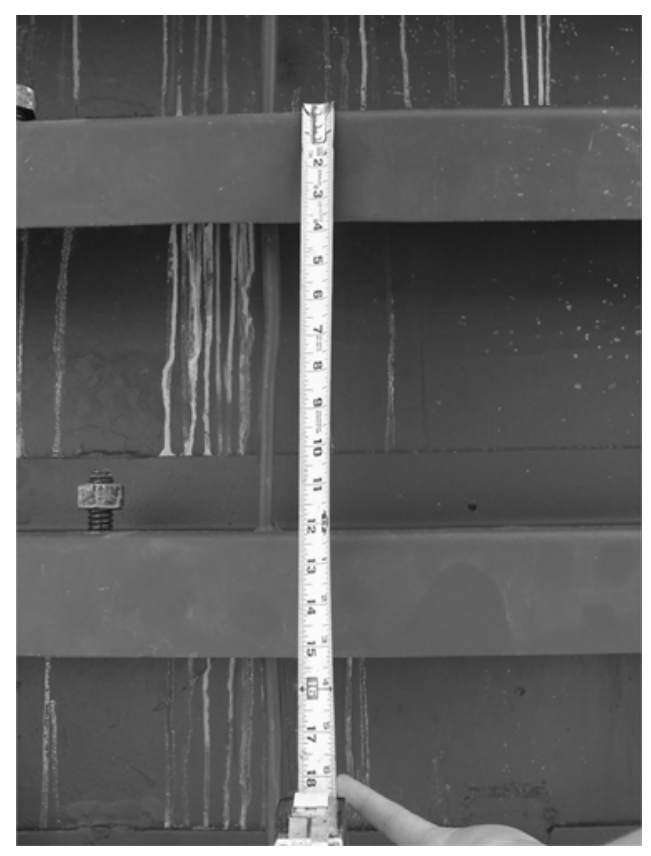

Fig. 3-Formwork stiffeners.

\section{Solar radiation}

The temperature prediction model uses the product of cloud cover factor and extraterrestrial solar radiation to calculate the surface horizontal solar radiation. This value is the total amount of direct and diffuse solar radiation that would strike a horizontal surface at ground level. ${ }^{14}$ The amount of solar radiation incident on the vertical surfaces of a column is different than the solar radiation incident on a horizontal surface because of differences in the angle between each surface and the incoming solar radiation. This difference also changes throughout the day and year as the position of the sun in the sky changes. Figure 2 shows the angles (measured in degrees) that are used to calculate the component of the solar radiation on the vertical concrete surface, where $\beta$ is the angle between the direct solar radiation and the ground, $\phi$ is the angle between the horizontal component of the direct solar radiation and south, $\psi$ is the angle between south and the vertical column normal, $\gamma$ is the angle between the horizontal component of the direct solar radiation and the vertical column normal, and $\theta_{v}$ is the angle between the direct solar radiation and the vertical column normal. ${ }^{15}$

Angles $\beta$ and $\psi$ are functions of the latitude $L_{a}$ and longitude $L_{o}$ of the column, apparent solar time expressed as an angle $H$ (degrees), and the solar declination $\delta$ (degrees). Equations (3) and (4) may be used to determine $\beta$ and $\psi^{15}$

$$
\begin{gathered}
\beta=\arcsin \left(\cos L_{a} \cos \delta \cos H+\sin L_{a} \sin \delta\right) \\
\psi=\arccos \left[\frac{\left(\sin \beta \sin L_{a}-\sin \delta\right)}{\left(\cos \beta \cos L_{a}\right)}\right]
\end{gathered}
$$

Angle $\theta_{v}$ (degrees) for a vertical surface is shown in Eq. (5) ${ }^{15}$

$$
\theta_{v}=\arccos (\cos \beta \cos \gamma)
$$

The apparent solar time (AST) (minutes) may be calculated according to Eq. (6) ${ }^{15}$

$$
\mathrm{AST}=\mathrm{LST}+\mathrm{ET}+4\left(\mathrm{LSM}-L_{O}\right)
$$

where LST is the local standard time (minutes from midnight), ET is the equation of time (minutes) as calculated in Eq. (7) to (10), ${ }^{16}$ and LSM is the local standard time meridian found in the weather data files. The equation of time (Eq. (6)) takes into account the change in the difference between local standard time and solar time during the year

$$
\begin{aligned}
& \text { For } D=1 \text { to } 106: \mathrm{ET}=-14.2 \times \sin (\pi \times(D+7) / 111) \\
& \text { For } D=107 \text { to } 166: \mathrm{ET}=4.0 \times \sin (\pi \times(D-106) / 59) \\
& \text { For } D=167 \text { to } 246: \mathrm{ET}=-6.5 \times \sin (\pi \times(D-166) / 80) \\
& \text { For } D=247 \text { to } 365: \mathrm{ET}=16.4 \times \sin (\pi \times(D-247) / 113)(10)
\end{aligned}
$$

where $D$ is the day of the year (Julian days). The apparent solar time is converted to $H$ using Eq. (11)

$$
H=\frac{\mathrm{AST}}{4}
$$

The normal solar radiation $E_{N}\left(\mathrm{~W} / \mathrm{m}^{2}\right)$ may be calculated from $E_{H}$ using Eq. (12) $)^{15}$

$$
E_{N}=\frac{E_{H}}{\sin \beta}
$$

The component of the normal solar radiation on a vertical column is shown in Eq. (13)

$$
E_{v}=E_{N} \cos \theta_{v}
$$

The solar radiation seen on a vertical column $E_{v}\left(\mathrm{~W} / \mathrm{m}^{2}\right)$, expressed in terms of the horizontal solar radiation, can be derived from Eq. (4), (11), and (12), and is expressed in Eq. (14)

$$
E_{v}=E_{H} \frac{\cos \gamma}{\tan \beta}
$$

The value of $E_{v}$ must account for the effects of shading. If $\gamma$ is between 90 and 270 degrees, the vertical surface will be shaded from the sun. If steel forms with horizontal bracing 
(such as stiffeners or walers) are used, $E_{v}$ must be adjusted. Figure 3 shows a close-up picture of stiffeners typically used with steel formwork. Figure 4 shows the shading effect that stiffeners have, where $\Omega$ (degrees) is the angle between horizontal and the shaded region, where $P_{h}$ is the width of the stiffener (m), $B_{h}$ is the height of the stiffener $(\mathrm{m}), S_{h}$ is the height of shading below the stiffener $(\mathrm{m})$, and $C_{h}$ is the distance between each stiffener $(\mathrm{m})$. The temperature prediction model assumes that the stiffeners are facing downwards, as shown in Fig. 3 and 4. Equation (15) shows the relationship between the percent of the forms that are sunny, $S_{u}$, and the position of the sun.

$$
S_{u}=\frac{C_{h}-B_{h}-P_{h} \frac{\tan \beta}{\tan \gamma}}{C_{h}} \times 100 \%
$$

The temperature prediction model assumes that the shading effect produces no local temperature extremes. Note that $E_{H}$ is a measured value, and the derivation to convert to $E_{v}$ is theoretical. As a result, some stability problems can occur in the model. For example, in a case where the calculated sunset occurs before the measured sunset, $E_{N}$ approaches infinity. This problem is corrected by limiting $E_{N}$ to the maximum solar radiation.

\section{Radiation exchange between vertical form surface and form cross bracing}

The radiation emitted from Surfaces 2 and 3 to Surface 1 in Fig. 4 is expressed in Eq. $(16)^{8}$

$$
q_{i j}^{\prime \prime}=A_{i} F_{i j} \alpha_{j} \varepsilon_{i} \sigma\left(T_{i}^{4}-T_{j}^{4}\right)
$$

where $i$ is Surface 2 or $3, j$ is Surface $1, q_{i j}^{\prime \prime}$ is the net rate radiation that leaves surface $i$ and gained by surface $j\left(\mathrm{~W} / \mathrm{m}^{2}\right)$, $A_{i}$ is the area of surface $i\left(\mathrm{~m}^{2}\right), F_{i j}$ is the view factor from surface $i$ to surface $j, \alpha_{j}$ is the absorptivity of surface $j, \varepsilon_{i}$ is the emissivity of surface $i, \sigma$ is the Stefan-Boltzmann constant $\left(=5.67 \times 10^{-8} \mathrm{~W} / \mathrm{m}^{2} \cdot \mathrm{K}^{4}\right), T_{i}$ is the temperature of surface $i(\mathrm{~K})$, and $T_{j}$ is the temperature of surface $j(\mathrm{~K})$. The view factor "is defined as the fraction of the radiation leaving surface I that is intercepted by surface J." 8 The view factor for steel formwork may be calculated by considering the horizontal and vertical parts of the stiffeners separately. The view factor for the horizontal part of the stiffeners (Surface 2 to Surface 1) may be calculated using Eq. $(17)^{8}$

$$
F_{i j}=\frac{1+\frac{P_{h}}{C_{h}}-\left[1+\left(\frac{P_{h}}{C_{h}}\right)^{2}\right]^{\frac{1}{2}}}{2}
$$

The view factor for the vertical portion of the form stiffeners (Surface 3 to Surface 1) may be calculated using Hottel's crossed string method to obtain Eq. (18) ${ }^{17}$

$F_{i j}=\left[\frac{\sqrt{P_{h}^{2}+B_{h}^{2}}+\sqrt{C_{h}^{2}+P_{h}^{2}}-P_{h}-\sqrt{\left(C_{h}-B_{h}\right)^{2}+P_{h}^{2}}}{2 \times B_{h}}\right](18)$

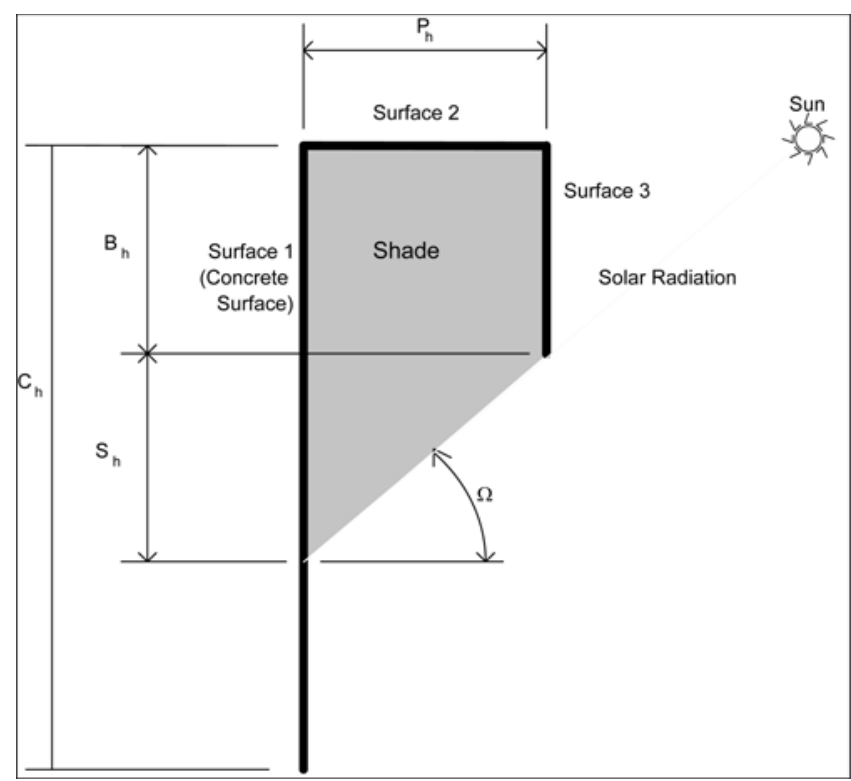

Fig. 4-Effect of stiffener on form shade.

\section{Atmospheric radiation}

Radiation is emitted from matter at a temperature above zero degrees Kelvin. Gas in the atmosphere emits radiation like all other matter. These gas particles follow the StefanBoltzmann law shown in Eq. (19)

$$
q_{a}^{\prime \prime}=\sigma \varepsilon_{a}\left(T_{a}\right)^{4}
$$

where $q_{a}^{\prime \prime}$ is the heat flux from the air $\left(\mathrm{W} / \mathrm{m}^{2}\right), \varepsilon_{a}$ is the emissivity of the air, and $T_{a}$ is the temperature of the air $(\mathrm{K})$. The emissivity is dependent on the atmospheric water vapor pressure $e_{a}$ (millibars), temperature, and cloud cover fraction as shown in Eq. (20) 12,18

$$
\varepsilon_{a}=C+1.24(1-C) \times\left(\frac{e_{a}}{T_{a}}\right)^{\frac{1}{7}}
$$

The saturated water vapor pressure $P_{w s}(\mathrm{kPa})$ is calculated using Eq. (21) for a temperature range of -100 to $0{ }^{\circ} \mathrm{C}\left(-148\right.$ to $\left.32{ }^{\circ} \mathrm{F}\right)$ and Eq. (22) for a temperature range of 0 to $200{ }^{\circ} \mathrm{C}\left(32 \text { to } 392{ }^{\circ} \mathrm{F}\right)^{15}$

$$
P_{w s}=\exp \left[\frac{C_{1}}{T_{a}}+C_{2}+C_{3} T_{a}+C_{4} T_{a}^{2}+C_{5} T_{a}^{3}+C_{6} T_{a}^{4}+C_{7} \ln \left(T_{a}\right)\right]
$$

where $C_{1}=-5.6745359 \times 10^{3}, C_{2}=-5.1523058 \times 10^{-1}, C_{3}=$ $-9.677843 \times 10^{-3}, C_{4}=6.2215701 \times 10^{-7}, C_{5}=2.0747825 \times$ $10^{-9}, C_{6}=-9.484024 \times 10^{-13}$, and $C_{7}=4.1635019$.

$$
P_{w s}=\exp \left[\frac{C_{8}}{T_{a}}+C_{9}+C_{10} T_{a}+C_{11} T_{a}^{2}+C_{12} T_{a}^{3}+C_{13} \ln \left(T_{a}\right)\right]
$$

where $C_{8}=-5.8002206 \times 10^{3}, C_{9}=-5.516256, C_{10}=$ $-4.8640239 \times 10^{-2}, C_{11}=4.1764768 \times 10^{-5}, C_{12}=-1.4452093$ $\times 10^{-8}$, and $C_{13}=6.5459673$.

The partial water vapor pressure $e_{a}(\mathrm{kPa})$ is calculated using Eq. (23) 
Table 4-Emissivity and absorptivity values for common materials

\begin{tabular}{c|c|c|c|c}
\hline Material & $\begin{array}{c}\text { Emissivity } \\
\text { values in } \\
\text { literature }\end{array}$ & $\begin{array}{c}\text { Emissivity } \\
\text { values used in } \\
\text { this model }\end{array}$ & $\begin{array}{c}\text { Absorptivity } \\
\text { values in } \\
\text { literature }\end{array}$ & $\begin{array}{c}\text { Absorptivity } \\
\text { values used in } \\
\text { this model }\end{array}$ \\
\hline Concrete & 0.88 to 0.93 & 0.92 & 0.23 to $0.59^{20}$ & 0.55 \\
\hline Soil & 0.93 to 0.96 & 0.92 & - & - \\
\hline Vegetation & 0.92 to 0.96 & 0.92 & - & - \\
\hline Rocks & 0.88 to 0.95 & 0.92 & - & - \\
\hline $\begin{array}{c}\text { Paint on } \\
\text { metallic } \\
\text { substrate }\end{array}$ & 0.96 to 0.97 & 0.95 (red), & 0.21 to $0.97^{8}$ & 0.72 (yellow) \\
\hline Wood & 0.82 to 0.92 & 0.92 & - & 0.6 \\
\hline
\end{tabular}

$$
e_{a}=R_{h} \times P_{w s} \times\left(\frac{10 \text { millibar }}{\mathrm{kPa}}\right)
$$

where $R_{h}$ is the air relative humidity (\%).

\section{Radiation from ground surface}

Radiation from the ground surface can interact with the column surface. This radiation follows the Stefan-Boltzmann law for radiation. ${ }^{8}$ Equation (24) shows the StefanBoltzmann law for the ground surface radiation that contacts the column ${ }^{8}$

$$
q_{g}^{\prime \prime}=\varepsilon_{g} \sigma T_{g}^{4}
$$

where $q_{g}^{\prime \prime}$ is the radiation seen by the column $\left(\mathrm{W} / \mathrm{m}^{2}\right), \varepsilon_{g}$ is the emissivity of the ground, and $T_{g}$ is the temperature of the ground $(\mathrm{K})$. The calculation of the ground surface temperature would require a separate heat transfer analysis; would vary greatly from one location to another; and would be very dependent on the individual location, shading conditions, and plant locations. To make the concrete surface calculations faster and less complex, several assumptions are made. First, the temperature prediction model assumes that $T_{g}$ is equal to the ambient temperature. The model also assumes that the area around the concrete is open (the concrete is not placed directly next to a wall or other vertical surface that emits radiation). Also, the stiffeners on the steel forms shade the column from radiation from the ground, which may be accounted for in the same manner as with solar radiation.

\section{Column irradiation}

The column emits radiation as part of the heat transfer process. The radiation emitted from the column is governed by the Stefan-Boltzmann law, as shown in Eq. (25)

$$
q_{c}^{\prime \prime}=\varepsilon_{c} \sigma T_{c}^{4}
$$

where $q_{c}^{\prime \prime}$ is the heat lost from the column $\left(\mathrm{W} / \mathrm{m}^{2}\right), \varepsilon_{c}$ is the emissivity of the concrete surface (concrete or formwork, whichever is exposed), and $T_{c}(\mathrm{~K})$ is the temperature of the concrete surface. When steel forms are used, the concrete surface temperature is used for the surface temperature because the steel forms provide little insulation against heat loss from the member. ${ }^{19}$ When wood forms or insulating blankets are used, a separate temperature node is used for $T_{c}$ because of the difference between the concrete surface temperature and form/blanket surface temperature. This is necessary to model the increased insulating properties of the form/blanket.

\section{Material properties to model radiation}

The emissivity term in the Stefan-Boltzmann law accounts for the efficiency of the surface in emitting radiation. Emissivity values range from 0 to 1 , with 1 being an ideal radiator called a blackbody. ${ }^{8}$ The emissivity for each material depends on the material temperature, material color, oxidation level, and amount of polishing. ${ }^{8}$ Common materials also do not absorb $100 \%$ of the radiation that contacts the surface. All incoming radiation heat fluxes are multiplied by the material radiation absorptivity, $\alpha$, to account for this inefficiency. Table 4 shows the emissivity and absorptivity of common relevant materials found in literature and those used in the temperature prediction model. The solar absorptivity of concrete is dependent on the color of the cementitious materials, aggregate type, concrete age, and state of weathering. ${ }^{20}$

\section{Convection model}

Heat is transferred from the concrete surface to the surrounding fluid (usually air or water) by convection. Convection is the energy transport from a surface to a surrounding fluid by diffusion (random fluid particle motion contacting the surface) and bulk motion of the fluid. Convection is governed by Newton's law of cooling, shown in Eq. $(26)^{8}$

$$
q_{c v}^{\prime \prime}=h\left(T_{S}-T_{\infty}\right)
$$

where $q_{c v}^{\prime \prime}$ is the convection heat flux $\left(\mathrm{W} / \mathrm{m}^{2}\right), h$ is the convection coefficient $\left(\mathrm{W} / \mathrm{m}^{2} \cdot \mathrm{K}\right), T_{s}$ is the surface temperature $(\mathrm{K})$, and $T_{\infty}$ is the fluid temperature $(\mathrm{K})$. In the case of the column, the fluid temperature may be approximated as $T_{a}$, the ambient temperature $(\mathrm{K})$.

Convection heat transfer can be divided up into two categories: free convection and forced convection. The bulk fluid motion in free convection is caused by buoyancy forces from differences in local fluid density. The local fluid density gradients are caused by local heating or cooling of the fluid in contact with the surface. In forced convection, the fluid motion is caused by an external source of fluid motion. In the case of concrete columns, the convection is a combination of free and forced convection. If the boundary layer air is heated by the column, the air's density will be lowered and the air will travel up the column. This is a result of free convection. The wind will also move the air around the column, creating forced convection. Equation (27) shows the relation used to calculate the convection coefficient due to forced and free convection ${ }^{15}$

$$
\begin{aligned}
h= & C \times 0.2782 \times\left[\frac{1}{T_{a v g}+17.8}\right]^{0.181} \\
& \times\left|T_{s}-T_{a}\right|^{0.266} \times \sqrt{1+2.8566 \times w}
\end{aligned}
$$

where $C$ is a heat flow constant, $T_{a v g}$ is the average air film temperature $\left({ }^{\circ} \mathrm{C}\right)$, and $w$ is the wind speed $(\mathrm{m} / \mathrm{s}) . T_{a v g}$ can be approximated by the average of $T_{a}$ and $T_{s} . C=10.15$ for bottom horizontal surface hotter than ambient or top horizontal surface cooler than ambient, $C=15.89$ for vertical surfaces, 
Table $5-r^{2}$ values for concrete members

\begin{tabular}{c|c|c|c|c|c}
\hline Name of member & $\begin{array}{c}\text { Total no. of temperature } \\
\text { sensors (Group 1) }\end{array}$ & $\begin{array}{c}\text { No. of temperature sensors } \\
\text { within 0.31 m of form or } \\
\text { finished surface (Group 2) }\end{array}$ & $\begin{array}{c}\text { No. of hours for each } \\
\text { temperature sensor }\end{array}$ & $\begin{array}{c}\text { Average } r^{2} \text { for Group 1 } \\
\text { temperature sensors } \\
\text { (range) }\end{array}$ & $\begin{array}{c}\text { Average } r^{2} \text { for Group 2 } \\
\text { temperature sensors } \\
\text { (range) }\end{array}$ \\
\hline Pedestal & 9 & 5 & 119 & $0.94(0.83$ to 0.98$)$ & $0.96(0.95$ to 0.98$)$ \\
\hline T-shaped bent cap & 16 & 10 & 120 & $0.88(0.52$ to 0.99$)$ & $0.83(0.52$ to 0.99$)$ \\
\hline Rectangular bent cap & 19 & 15 & 286 & $0.97(0.88$ to 0.98$)$ & $0.96(0.88$ to 0.98$)$ \\
\hline Dolphin 1 & 18 & 7 & 262 & $0.89(0.71$ to 0.99$)$ & $0.87(0.71$ to 0.97$)$ \\
\hline Dolphin 2 & 27 & 8 & 316 & $0.86(0.50$ to 0.99$)$ & $0.75(0.50$ to 0.95$)$ \\
\hline Footing 1 & 2 & 1 & 51 & $0.68(0.67$ to 0.69$)$ & 0.69 \\
\hline Footing 2 & 7 & 1 & 168 & $0.97(0.89$ to 0.99$)$ & 0.89 \\
\hline Footing 3 & 2 & 1 & 49 & $0.73(0.69$ to 0.78$)$ & 0.69 \\
\hline Footing 4 & 13 & 7 & 221 & $0.90(0.83$ to 0.95$)$ & $0.89(0.88$ to 0.95$)$ \\
\hline Column 1 & 3 & 2 & 336 & $0.78(0.61$ to 0.88$)$ & $0.74(0.61$ to 0.88$)$ \\
\hline Column 2 & 3 & 2 & 336 & $0.93(0.85$ to 0.98$)$ & $0.90(0.85$ to 0.95$)$ \\
\hline Pilaster & 18 & 7 & 316 & $0.89(0.54$ to 0.99$)$ & $0.77(0.54$ to 0.99$)$ \\
\hline
\end{tabular}

and $C=20.4$ for bottom horizontal surface cooler than ambient or top horizontal surface hotter than ambient.

The convection equation shown in Eq. (27) is for pipes and flat surfaces. Equation (27) was formulated for relatively smooth surfaces tested in wind tunnels. ${ }^{15,21}$ To correct for surface roughness, the convection coefficient $h$ may be multiplied by a roughness multiplier $R_{f}$. Concrete has been shown to have a roughness multiplier of 1.52 and is used after the forms are removed. ${ }^{22}$ The steel form's multiplier is used before the formwork is removed, which is assumed to be smooth with a roughness multiplier of 1 . The wind speed used in Eq. (27) is for the average main wind stream speed. Local variations in wind speed from turbulence or obstructions may cause some errors in the calculations. ${ }^{21}$

\section{CONCRETE MEMBER TEMPERATURE PREDICTION}

Concrete temperatures for the structural elements listed in Table 1 were predicted using the model described in this paper. The measured minimum and maximum weather data were used in calculating the predicted concrete temperatures. If the minimum and maximum weather data were not used, the comparison between the predicted and measured concrete temperatures would reflect the variation in the weather from the 30 -year average weather values. The shape of the measured weather data only deviated significantly from the average weather data during extreme weather events (such as thunderstorms). The measured concrete hydration parameters obtained from semi-adiabatic calorimetry were also used in the analysis.

\section{RESULTS AND DISCUSSION}

The concrete temperatures predicted by the model described in this paper were compared with the measured values. The value for each temperature sensor was compared with the temperature predicted. Table 5 shows the average coefficient of determination $r^{2}$ value for all of the temperature sensors (Group 1) in the 12 concrete members. The average coefficient of determination $r^{2}$ value for temperature sensors within $0.31 \mathrm{~m}(1 \mathrm{ft})$ of the concrete surface (Group 2) for each concrete member is also shown in Table 5. The analysis was performed comparing the hourly temperatures for each temperature sensor for the length of time indicated in Table 5. The high average $r^{2}$ (above 0.8) values calculated for most members indicate that the model
Table 6-Member predicted to measured temperature average absolute error

\begin{tabular}{c|c|c}
\hline Name of member & $\begin{array}{c}\text { Average absolute error, } \\
{ }^{\circ} \mathrm{C}\left({ }^{\circ} \mathrm{F}\right)\end{array}$ & $\begin{array}{c}\text { Average absolute error } \\
\text { range, }{ }^{\circ} \mathrm{C}\left({ }^{\circ} \mathrm{F}\right)\end{array}$ \\
\hline Pedestal & $2.0(3.6)$ & 1.0 to $4.5(1.8$ to 8.1$)$ \\
\hline T-shaped bent cap & $2.6(4.7)$ & 1.0 to $6.0(1.8$ to 10.9$)$ \\
\hline Rectangular bent cap & $1.6(2.9)$ & 1.2 to $2.8(2.1$ to 5.0$)$ \\
\hline Dolphin 1 & $0.5(1.0)$ & 0.1 to $3.7(0.2$ to 6.7$)$ \\
\hline Dolphin 2 & $2.3(4.1)$ & 0.6 to $3.8(1.1$ to 6.9$)$ \\
\hline Footing 1 & $4.6(8.4)$ & 3.5 to $5.8(6.4$ to 10.4$)$ \\
\hline Footing 2 & $0.8(1.4)$ & 0.5 to $1.6(1.0$ to 3.0$)$ \\
\hline Footing 3 & $4.3(7.8)$ & 2.7 to $5.9(4.9$ to 10.7$)$ \\
\hline Footing 4 & $1.3(2.3)$ & 0.7 to $1.6(1.3$ to 2.9$)$ \\
\hline Column 1 & $2.6(4.7)$ & 2.0 to $3.5(3.5$ to 6.3$)$ \\
\hline Column 2 & $1.6(2.8)$ & 1.4 to $1.8(2.6$ to 3.2$)$ \\
\hline Pilaster & $1.6(2.9)$ & 0.8 to $2.9(1.5$ to 5.1$)$ \\
\hline
\end{tabular}

accurately simulated the overall concrete temperature development. Footings 1 and 3 and Column 1, however, showed lower average $r^{2}$ values. Column 1 showed a lower $r^{2}$ value because one of the exterior points did not correctly capture the magnitude of daily temperature fluctuations after the forms were removed. It is not known why Footings 1 and 2 showed lower $r^{2}$ values. The heat of hydration for the concrete used in Footings 1 and 3 was not measured. The heat of hydration from tests performed a few months earlier on the same mixture proportions were used in the analysis, and could be the cause of the associated error. The mean of the average absolute error between the predicted and measured temperature for each member and the range for individual sensors is shown in Table 6 . The average absolute error is calculated using Eq. $(28)^{23}$

$$
\mathrm{AAE}=\frac{\Sigma(|\hat{y}-y|)}{n}
$$

where $\mathrm{AAE}$ is the average absolute error, $\hat{y}$ is the predicted temperature $\left({ }^{\circ} \mathrm{C}\right), y$ is the measured temperature, and $n$ is the number of data points used in the analysis. The average absolute error for the members ranged from 0.5 to $4.6^{\circ} \mathrm{C}(1.0$ to $8.4^{\circ} \mathrm{F}$ ), indicating that the magnitude of the predicted temperatures matches well with the measured values. The 
Table 7-Comparison of predicted to measured maximum concrete temperature

\begin{tabular}{c|c|c|c}
\hline $\begin{array}{c}\text { Name of } \\
\text { member }\end{array}$ & $\begin{array}{c}\text { Maximum } \\
\text { temperature } \\
\text { measured, }{ }^{\circ} \mathrm{C}\left({ }^{\circ} \mathrm{F}\right)\end{array}$ & $\begin{array}{c}\text { Maximum } \\
\text { temperature } \\
\text { predicted, }{ }^{\circ} \mathrm{C}\left({ }^{\circ} \mathrm{F}\right)\end{array}$ & $\begin{array}{c}\text { Difference in } \\
\text { maximum } \\
\text { temperature, }{ }^{\circ} \mathrm{C}\left({ }^{\circ} \mathrm{F}\right)\end{array}$ \\
\hline Pedestal & $74.0(165.2)$ & $71.7(161.0)$ & $-2.3(-4.1)$ \\
\hline $\begin{array}{c}\text { T-shaped bent } \\
\text { cap }\end{array}$ & $67.5(153.5)$ & $67.2(153.0)$ & $-0.3(-0.5)$ \\
\hline $\begin{array}{c}\text { Rectangular } \\
\text { bent cap }\end{array}$ & $53.5(128.3)$ & $52.8(127.0)$ & $-0.7(-1.3)$ \\
\hline Dolphin 1 & $63.0(145.4)$ & $65.1(149.2)$ & $2.1(3.8)$ \\
\hline Dolphin 2 & $65.5(149.9)$ & $65.5(149.9)$ & $0.0(0.0)$ \\
\hline Footing 1 & $63.0(145.4)$ & $61.1(142.0)$ & $-1.9(-3.4)$ \\
\hline Footing 2 & $56.1(133.0)$ & $57.3(135.2)$ & $1.2(2.2)$ \\
\hline Footing 3 & $64.0(147.2)$ & $60.6(141.1)$ & $-3.4(-6.1)$ \\
\hline Footing 4 & $57.2(135.0)$ & $57.2(135.0)$ & $0.0(0.0)$ \\
\hline Column 1 & $57.8(136.0)$ & $55.9(132.6)$ & $-1.9(-3.4)$ \\
\hline Column 2 & $73.0(163.4)$ & $76.6(169.9)$ & $3.6(6.5)$ \\
\hline Pilaster & $54.5(130.1)$ & $52.1(125.8)$ & $-2.4(-4.3)$ \\
\hline
\end{tabular}

Table 8-Comparison of predicted to measured concrete temperature difference

\begin{tabular}{c|c|c|c}
\hline $\begin{array}{c}\text { Name of } \\
\text { member }\end{array}$ & $\begin{array}{c}\text { Maximum } \\
\text { temperature } \\
\text { measured, }{ }^{\circ} \mathrm{C}\left({ }^{\circ} \mathrm{F}\right)\end{array}$ & $\begin{array}{c}\text { Maximum } \\
\text { temperature } \\
\text { predicted, }{ }^{\circ} \mathrm{C}\left({ }^{\circ} \mathrm{F}\right)\end{array}$ & $\begin{array}{c}\text { Difference in } \\
\text { maximum } \\
\text { temperature, }{ }^{\circ} \mathrm{C}\left({ }^{\circ} \mathrm{F}\right)\end{array}$ \\
\hline $\begin{array}{c}\text { Pedestal } \\
\begin{array}{c}\text { T-shaped bent } \\
\text { cap }\end{array}\end{array}$ & $24.0(43.2)$ & $20.3(36.5)$ & $3.7(6.7)$ \\
\hline $\begin{array}{c}\text { Rectangular } \\
\text { bent cap }\end{array}$ & $15.5(27.9)$ & $16.7(30.1)$ & $1.1(2.2)$ \\
\hline Dolphin 1 & $40.0(72.0)$ & $40.3(72.5)$ & $0.3(0.5)$ \\
\hline Dolphin 2 & $31.0(55.8)$ & $31.8(57.2)$ & $0.8(1.4)$ \\
\hline Footing 1 & $21.5(38.7)$ & $18.9(34.0)$ & $2.6(4.7)$ \\
\hline Footing 2 & $13(23.4)$ & $12.3(22.1)$ & $0.7(1.3)$ \\
\hline Footing 3 & $23.0(41.4)$ & $20.1(36.2)$ & $2.9(5.2)$ \\
\hline Footing 4 & $23.0(41.4)$ & $20.8(37.4)$ & $2.2(4.0)$ \\
\hline Column 1 & $22.2(40.0)$ & $19.3(34.7)$ & $2.9(5.3)$ \\
\hline Column 2 & $33.5(60.3)$ & $30.2(54.4)$ & $3.3(5.9)$ \\
\hline Pilaster & $36.5(65.7)$ & $33.2(59.8)$ & $3.3(5.9)$
\end{tabular}

maximum temperature and maximum temperature difference (the maximum difference between the maximum temperature and the minimum temperature anywhere in the concrete member) measured for each concrete member was compared with the predicted values, as shown in Tables 7 and 8. The maximum predicted temperature and temperature difference for each member were calculated from the predicted temperatures at the temperature sensor locations. It is expected that the actual maximum temperature differences will be greater than those measured because the minimum temperature in the concrete member could not always be measured because of restrictions on temperature sensor locations. The boundary condition models described in this paper predicts the concrete surface temperature for the concrete members well. Figure 5 shows the predictedversus-measured temperature for a temperature sensor placed near the steel formwork on Column 2. The model also provides a good estimate of the maximum temperature in the concrete, with a maximum error of $4.9 \%$. The model output differed by as much as $17.6 \%$ in predicting the maximum temperature difference in the concrete.

Local temperature effects due to formwork shading, as shown in Fig. 3, were investigated by installing additional

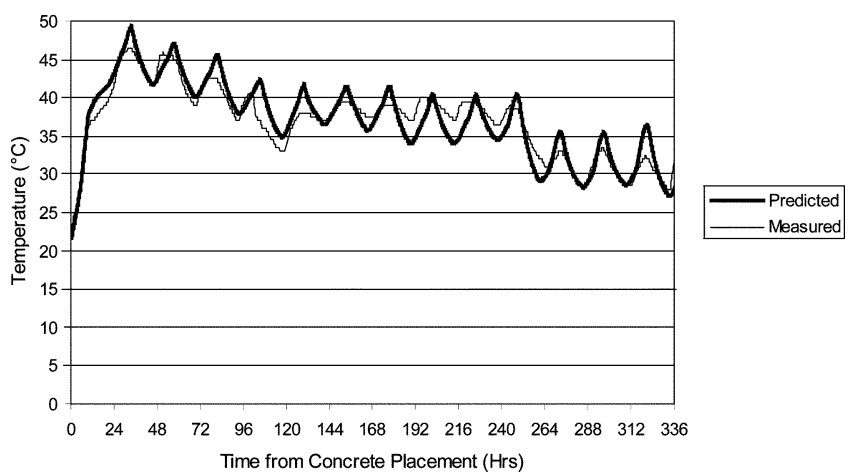

Fig. 5-Measured versus predicted temperature for surface temperature sensor on Column 2.

temperature sensors vertically close to the formwork on Column 2. Five temperature sensors were placed $25 \mathrm{~mm}$ (1 in.) from the surface vertically over a length of $0.4 \mathrm{~m}$ (16 in.). Five additional temperature sensors were placed $50 \mathrm{~mm}(2 \mathrm{in}$.) from the surface vertically over a length of $0.46 \mathrm{~m}$ (18 in.) on an adjacent side where a thick polyurethane form-liner was used for aesthetic reasons. The temperature sensors placed on the side without the form-liner differed by a maximum of $3.5^{\circ} \mathrm{C}\left(6.3{ }^{\circ} \mathrm{F}\right)$ over a period of 2 weeks. The sensors placed on the side with the form-liner differed by a maximum of $2{ }^{\circ} \mathrm{C}$ $\left(3.6^{\circ} \mathrm{F}\right)$ over the same period of time. The surface temperature data show that an average shaded surface value may be used with only a minor loss in accuracy of the model because of the averaging effect of the heat transfer in the vertical direction.

Some variation between measured and predicted temperature data is to be expected. Rapid and short-lived temperature variations occur in the microclimate surrounding the instrumented concrete members. The data analysis showed that the boundary conditions model, using average temperature data scaled for actual maximum and minimum values, did provide an acceptable result when predicting the concrete temperature. When the assumptions associated with the boundary condition models are not met, the $r^{2}$ value decreases dramatically. Rain events, snow events, and concrete freezing were not considered in the heat transfer analysis. When precipitation events occurred, the model accuracy was reduced. The reduction in accuracy will be highly variable and will depend on the magnitude and duration of the event. For this reason, these extreme events are not modeled.

\section{CONCLUSIONS}

A model was presented to characterize the heat transfer at the top and side surfaces of concrete members. The model includes components for calculating the radiation heat transfer components due to solar radiation, atmospheric radiation, ground surface radiation, radiation exchange with formwork bracing, and irradiation. The model also includes a method to characterize the effects of free convection, forced convection, and surface roughness. The finite difference heat transfer model was compared with concrete temperature data collected from 12 concrete members of varying geometry, formwork, location, construction methods, and materials. The accuracy of the model may be reduced when model assumptions (location of walls and rain events) are violated.

\section{ACKNOWLEDGMENTS}

The authors wish to express their gratitude to the Texas Department of Transportation through Project $0-4563$ for funding this research and providing access to concrete construction sites. The advice and support of 
R. Browne and T. Yarbrough of the Texas Department of Transportation and R. Crowson of the Central Texas Turnpike Authority is greatly appreciated.

\section{NOTATION}

\begin{tabular}{|c|c|c|}
\hline $\mathrm{C}$ & $=$ & ASTM C 618 Class C fly ash ${ }^{24}$ \\
\hline $\mathrm{CG}$ & $=$ & crushed granite \\
\hline CL & $=$ & crushed limestone \\
\hline $\mathrm{F}$ & $=$ & ASTM C 618 Class F fly $\operatorname{ash}^{24}$ \\
\hline GGBFS & $=$ & ground-granulated blast-furnace slag \\
\hline HRWR & $=$ & ASTM C 494 Type F high-range water-reducing admixture 25 \\
\hline LRWR & $=$ & ASTM C 494 Type A water-reducing admixture 25 \\
\hline MRWR & $=$ & mid-range water reducer \\
\hline SNS & $=$ & siliceous natural sand \\
\hline SRG & $=$ & siliceous river gravel \\
\hline
\end{tabular}

\section{REFERENCES}

1. Day, R. L., "The Effect of Secondary Ettringite Formation on the Durability of Concrete: A Literature Analysis," Research and Development Bulletin RD108T, Portland Cement Association, Skokie, Ill., 1992, pp. 59, 83-84.

2. Schindler, A. K., "Effect of Temperature on Hydration of Cementitious Materials," ACI Materials Journal, V. 101, No. 1, Jan.-Feb. 2004, pp. 72-81.

3. van Breugel, K., "Prediction of Temperature Development in Hardening Concrete," RILEM Report 15, Prevention of Thermal Cracking in Concrete at Early Ages, R. Springenshmid, ed., E\&FN Spon, London, UK, 1998, pp. 51- 75 .

4. Wojcik, G. S., and Fitzjarrald, D. R., "Energy Balances of Curing Concrete Bridge Decks," Journal of Applied Meteorology, V. 40, No. 11, 2001, pp. 2003-2025.

5. Wojcik, G. S.; Fitzjarrald, D. R.; and Plawsky, J. L., "Modeling the Interaction between the Atmosphere and Curing Concrete Bridge Decks with the SLABS Model," Meteorological Applications, V. 10, 2003, pp. 1-22.

6. Hermansson, A., "Mathematical Model for Calculation of Pavement Temperatures," Transportation Research Record, V. 1764, 2001, pp. 180-188.

7. Gilliland, J. A., and Dilger, W. H., "Modeling Concrete Temperature Measured During Construction of the Confederation Bridge," Proceedings of the Annual Conference of the Canadian Society for Civil Engineering, Sherbrooke, Québec, Canada, May 27-30, 1997, pp. 187-196.

8. Incropera, F. P., and Dewitt, D. P., Fundamentals of Heat and Mass Transfer, John Wiley \& Sons, Inc., New York, 2002, 931 pp.

9. RILEM Technical Committee 119-TCE, "Adiabatic and Semi-Adiabatic Calorimetry to Determine the Temperature Increase in Concrete due to Hydration Heat of Cement," RILEM Report 15, Prevention of Thermal Cracking in Concrete at Early Ages, R. Springenshmid, ed., E\&FN Spon,
London, UK, 1998, pp. 315-330.

10. Ramaiah, S. V.; Dossey, T.; and McCullough, B. F., "An Investigation of the Thermacron ${ }^{\circledR}$ I-button for Early-Age and Long-Term Temperature," TRB 2002 Annual Meeting, 2002, 19 pp. (CD-ROM)

11. National Climatic Data Center, "Solar and Meteorological Surface Observational Network," Version 1.0, 1993. (CD-ROM)

12. Wojcik, G. S., "Effects of Atmospheric and Construction Conditions on Concrete Equivalent Ages," ACI Materials Journal, V. 101, No. 5, Sept.-Oct. 2004, pp. 376-384.

13. Freedman J. M.; Fitzjarrald, D. R.; Moore, K. E.; and Sakai, R. K., "Boundary Layer Clouds and Vegetation-Atmosphere Feedbacks," Journal of Climate, V. 14, 2001, pp. 180-197.

14. National Climatic Data Center, "NSRDB Synoptic Format," 2003, 12 pp. (CD-ROM)

15. ASHRAE, "1993 ASHRAE Handbook," American Society of Heating, Refrigerating and Air-Conditioning Engineers, Inc., Atlanta, Ga., 1993.

16. Watt Engineering, Ltd., "On the Nature and Distribution of Solar Radiation," U.S. Department of Energy, U.S. Government Printing Office Stock No. 016-000-00044-5, 1978, p. 57.

17. Siegel, R., and Howell, J. R., Thermal Radiation Heat Transfer, Hemisphere Publishing Corp., Washington D.C., 1992, 1072 pp.

18. Brutsaert, W., "On a Derivable Formula for Longwave Radiation from Clear Skies," Water Resources Research, V. 11, 1975, pp. 742-744.

19. ACI Committee 207, "Effect of Restraint, Volume Change, and Reinforcement on Cracking in Massive Concrete (ACI 207.2R-95)," American Concrete Institute, Farmington Hills, Mich., 1995, pp. 3-10.

20. Levinson, R., and Akbari, H., "Effects of Composition and Exposure on the Solar Reflectance of Portland Cement Concrete," Cement and Concrete Research, V. 32, 2002, pp. 1679-1698.

21. ASTM C 680, "Standard Practice for Estimate of the Heat Gain or Loss and the Surface Temperatures of Insulated Flat, Cylindrical, and Spherical Systems by Use of Computer Programs," ASTM International, West Conshohocken, Pa., 2004, 22 pp.

22. Clear, R. D.; Gartland, L.; and Winkelmann, F. C., "An Empirical Correlation for the Outside Convective Air-Film Coefficient for Horizontal Roofs," Energy and Buildings, V. 35, 2003, pp. 797-811.

23. Carino, N. J., and Tank, R. C., "Maturity Functions for Concretes Made with Various Cements and Admixtures," ACI Materials Journal, V. 89, No. 2, Mar.-Apr. 1992, pp. 188-196.

24. ASTM C 618, "Standard Specification for Coal Fly Ash and Raw or Calcined Natural Pozzolan for Use in Concrete," ASTM International, West Conshohocken, Pa., 2003, 3 pp.

25. ASTM C 494, "Standard Specification for Chemical Admixtures for Concrete,” ASTM International, West Conshohocken, Pa., 1999, 9 pp. 